\title{
Determinant Factors in Purchasing Korean Skin Care Products
}

\author{
Keshia Yohana Tanu Christine ${ }^{1}$, Sesilya Kempa $^{1 *}$, and Zane Vincēviča-Gaile ${ }^{2}$ \\ ${ }^{1}$ Faculty of Business and Economics, Petra Christian University, Siwalankerto 121-131, \\ Surabaya 60236, Indonesia \\ ${ }^{2}$ Faculty of Geography and Earth Sciences, University of Latvia, Riga LV-1050, Latvia
}

\begin{abstract}
The demand and business opportunities in the skin and facial beauty sector have increased in the last $10 \mathrm{yr}$. The beauty and personal care industry in Indonesia grows on average of $12 \%$, with a market value of $33 \times 10^{9}$. This research emphasizes the presence of the influence of attitude, subjective norm, and perceived behavioral control on the purchase intention of skincare products that are moderated by the country of origin. The data collection is conducted by distributing questionnaires to a total of 130 respondents. Data obtained through a questionnaire are then processed with Smart Partial Least Square (PLS). The results in this study prove that the attitude and perceived behavioral control significantly influence the purchase intention while the Subjective norm does not significantly influence the purchase intention. On the other hand, the country of origin is not able to strengthen the influence between attitude, subjective norm, and perceived behavioral control on the purchase intention of skincare products.
\end{abstract}

Keywords: Consumer attitude, country of origin image, perceived behavioral control, skincare buying intention, subjective norm.

\section{Introduction}

Surabaya becomes the city with the second-largest market center in Indonesia. The malls in Surabaya are not only selling daily necessities but also selling other lifestyle necessities, such as facial beauty products for both men and women. This is proven by the high demand and business growth in the skin and facial beauty sector, which, in the last $10 \mathrm{yr}$, The Beauty industry in Indonesia experienced an average growth of $12 \%$ with an equivalent market value value of IDR $33 \times 10^{9}$ in 2016. It is estimated that in 2020 there will be a growth of the beauty industry in Indonesia even exceeding the growths in the countries of Southeast Asia so as to provide enormous potential [1].

There are many Korean cosmetics and skincare brands in Surabaya, including Innisfree. Currently, in choosing their skincare and beauty products, the consumers will tend to look more at the country of origin of a brand. Furthermore, the attitude (or someone's feelings like or dislike to a certain product), Subjective norm (perception of a consumer to make a product purchase process), and perceived behavioral control (or beliefs that individuals

\footnotetext{
*Corresponding author: sesilya.kempa@petra.ac.id
} 
accept to have a thing or not) are expected to able to increase the likelihood of purchase intention of the consumers to buy a skin care product.

This research is a modification from previous research by [2], entitled "Exploring purchase intention of green skincare products using the theory of planned behavior: Testing the moderating effects of country of origin and price sensitivity." This research also adopts the concept of the Theory of Planned Behavior [2]. The Theory of Planned Behavior (TPB) discusses some behavior-forming factors, and one of which is the intention that is also based on attitude, subjective norm, and perceived behavioral control [3]. The use of the country of origin (country image) effect is treated as the moderation variable because it will see the interaction of the country of origin effects to each forming behavior based on TPB theory. It is believed that the country of origin influences high or low purchase intentions that occur in a product. So the existence of this moderating variable is important to know whether it can strengthen or weaken the occurrence of purchase intention.

\section{Literature review}

\subsection{Theory of planned behavior (TPB)}

This study uses the Theory of Planned Behavior (TPB) as the grand theory of research on behavior. TPB theory is related to attitude, subjective norm, and perceived behavioral control [4]. The country of origin element is a form of attitude towards the image of a country of origin of the product. TPB theory is very suitable to be used to explain various kinds of behaviors and attitudes possessed by potential consumers of a product in forming a purchase intention by consumers. TPB can be associated with purchase intention, which means that consumers' buying interest is influenced by the attitudes that consumers have of a product, from the country of origin of the product, the quality of the product, or the brand of the product that is familiar to the consumer's ear.

\subsection{Attitude}

According to [5], attitude is a mental and nervous connection with readiness to respond, organized through experience, and has a direct and dynamic influence on behavior.

\subsection{Subjective norm}

According to [4], the Subjective norm is a function that is based on beliefs called normative beliefs, namely beliefs about the approval and/or disapproval of a person or group that is important for an individual to a behavior. According to [6], subjective norms are formed because of the existence of normative beliefs and motivations from references that are trusted by consumers.

\subsection{Perceived behavioral control}

Perceived behavioral control is an individual's perception of the control, it has in connection with a particular behavior [4]. Ajzen [3] states that intention and perceived behavioral control affect a behavior carried out by individuals, but in general, intention and perceived behavioral control itself have a significant relationship with each other.

\subsection{Country of origin}

Country of origin (COO) is information that is often used by consumers when evaluating a product [7]. Country of origin is producing countries for products that support people's mentality and confidence in the products produced [8]. 


\subsection{Purchase Intention}

Purchase intention is a model of a person's attitude towards the object of goods, which is very suitable in measuring attitudes toward a certain class of products, services, or brands [9]. Setiadi [5] states that buying interest is formed from consumer attitudes toward products that consist of consumer trust in brands and brand evaluations. Kotler and Keller [8], argue that buying interest is in a position after the consumer evaluates alternatives before making a purchase decision. It is because, during the evaluation stage of the purchasing decision process, consumers form an interest in certain brands for a selection [8].

\subsection{Hypothesis development}

\subsubsection{The influence of country of origin on consumer purchase intention}

Previous studies on the effect of country of origin on mobile phones brands from China have shown how the country of origin influences the purchase intention [10]. Also besides, previous studies on the effect of country of origin on green skincare products in Taiwan have shown how the country of origin influences the purchase intention [2]. Therefore, the country of origin the product is one of the necessary factors that can impact to consumer purchase intention.

\subsubsection{Relationship between concept attitude to purchase intention}

Ajzen [4] argues that attitude toward this behavior is determined by beliefs about the consequences of a behavior, or briefly called behavioral beliefs. Previous studies on the effect of attitude on green skincare products in Taiwan show how attitude influences the purchase intention [2]. Therefore, attitude is one of the important factors that can influence purchase intention.

\subsubsection{Relationship between concept subjective norm to purchase intention}

Ajzen [3] states that in some behaviors, social referrals are considered important in the formation of an attitude and can shape the behavior of parents, married partners, friends, coworkers, and other references related to behavior. Previous studies on the effect of subjective norms on green skincare products in Taiwan shows how subjective norms affecting the occurrence of purchase intentions [2]. Therefore, the Subjective norm is one of the important factors that can influence the purchase intention

\subsubsection{Relationship between concept perceived behavioral control on purchase intention}

Perceived behavioral control or PBC can influence behavior directly and indirectly. Indirect influence is carried out by influencing one's intention to act a certain behavior. PBC can also be seen as a person's self-efficacy to bring up behavior. Ajzen [3] states that intentions and perceived behavioral control are influential on a behavior carried out by individuals, but in general, intentions and $\mathrm{PBC}$ do not have a significant relationship. Previous studies on the effect of perceived behavioral control on green skincare products in Taiwan showed how perceived behavioral control influences the purchase intention [2].

\subsubsection{The role of country of origin in the effect of attitude on purchase intention}

The country of origin is defined as a manufacturing country that has a big influence on making consumers' perceptions of the positive or negative of a product. Ajzen [4] argues that attitude toward this behavior is determined by beliefs about the consequences of 
behavior or briefly called behavioral beliefs. Overall, the individual's image of the country of origin is the extent to which manufacturing affects the evaluation of consumer attitudes towards products. Therefore, the country of origin is one of the important factors that can moderate attitude towards purchase intention.

\subsubsection{The role of country of origin in the effect of subjective norms on purchase intention}

Marhaini [11] writes a person's behavior depends on intention, then intention in behavior depends on attitude and subjective norms. On the other hand, belief in behavior and evaluation will determine behavior. Normative beliefs and motivation to follow the opinions of others will determine subjective norms. As a whole, the individual's image of the country of origin is the extent to which manufacturing affects the consumer's evaluation of the product. Therefore, the effect of country of origin in moderating subjective norms on the purchase intention.

\subsubsection{The role of country of origin in the effect of perceived behavioral control on purchase intention}

Perceived behavioral control is related to available resources and opportunities to do something [12]. As a whole, the individual's image of the country of origin or country the produce the product is the extent to which the production for manufacturing affects the consumer's evaluation of the product. Therefore, country of produce the product is one of the necessary factors that can moderate perceived behavioral control over purchase intention.

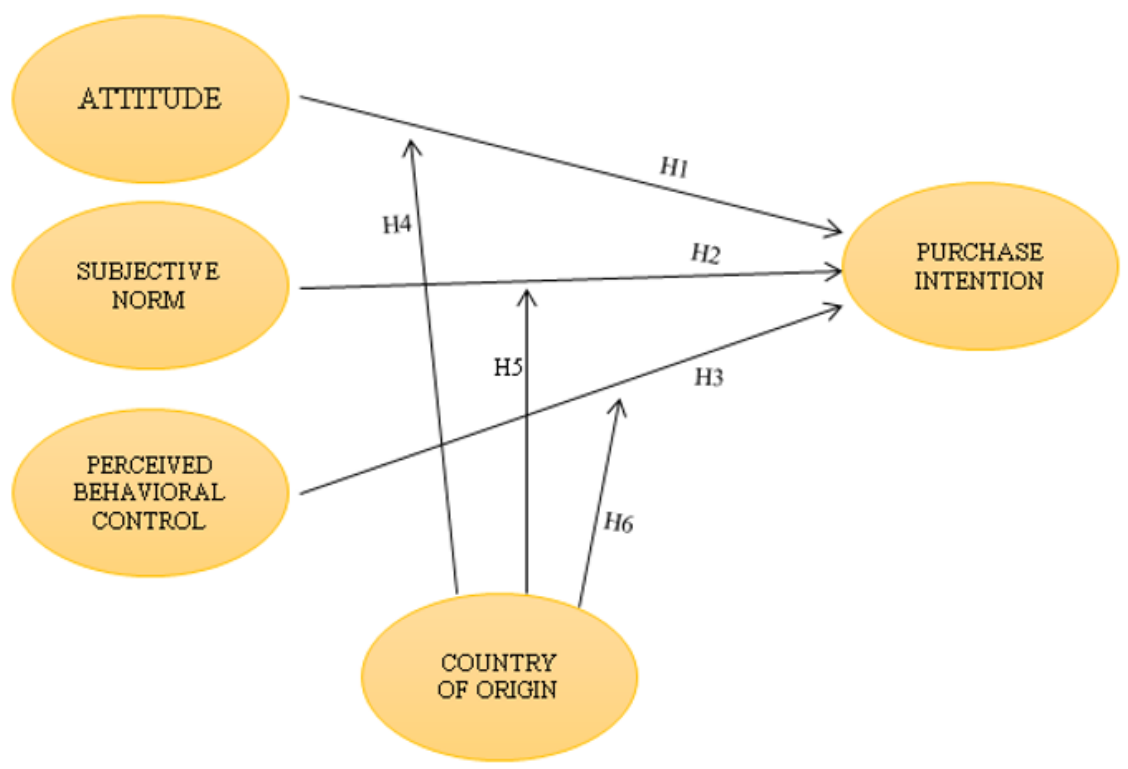

Fig. 1. Research model 


\section{Research Methods}

In this research, causal research is used. The method used is quantitative, and the data are collected by distributing questionnaires to determine responses from consumers regarding the impact of attitude, subjective norm, and perceived behavioral control consumer through the country of origin variable as a moderating variable directly affecting purchase intention.

The population in this study are all respondents who know Korean brand beauty products, but never buy Korean brand beauty products and intended to buy Korean brand beauty products in Surabaya. Hair et al., say for the determination of the sample from the unknown population are following the formula of [13]:

$$
\text { Sample }=\text { number of questionnaire questions } \times 5
$$

So, the sample used is 130 obtained from $26 \times 5$.

The sampling technique in this study uses a purposive sampling a part of nonprobability sampling. The characteristics sample for this resaerch are the respondents in this study are women who know skincare products from Korea, know Korean skincare brands, never buy any Korean skincare products, intend to buy Korean brand skincare products, and a minimum age of $17 \mathrm{yr}$ old (because that age it is considered old enough to make a purchasing decision). The data collection method used in this study is the survey method. Data obtained through a questionnaire for descriptive analysis will be processed using a computer program called IBM SPSS 16.0. Testing the outer model, inner model, and hypothesis will be done by the Partial Least Square with a computer program called SmartPLS 3.0

\section{Results}

Analysis of the model using Partial Least Square (PLS) using the SmartPLS program is explained as follows:

\subsection{Outer model}

Outer model is used to measure whether the predetermined indicators have been able to measure the variables used, and can be said to be an appropriate gauge for the variable.

\subsection{Convergent validity}

Convergent validity is the measurements the validity the items requested as a gauge of the variable are needed. The measurement items specified are like the measurement items of a variable determined at least 0.7 . The results of the correlation between the indicator with the contract, as shown in Table 1.

On the Table 1, where that all of indicator items in this study have a loading factor value greater than 0.70 so that it can be concluded that all of them have fulfillment with the value of validity as a measurement tool for the value of orignal sample estimate each of these dimensions is above 0.70 . 
Table 1. Convergent validity

\begin{tabular}{|c|c|c|c|}
\hline & $\begin{array}{c}\text { Original sample } \\
\text { estimate }\end{array}$ & p-value & Information \\
\hline \multicolumn{4}{|c|}{ Attitude $\left(\mathbf{X}_{1}\right)$} \\
\hline $\mathbf{X}_{1.1}$ & 0.827 & 0.000 & Valid \\
\hline $\mathrm{X}_{1.2}$ & 0.858 & 0.000 & Valid \\
\hline $\mathrm{X}_{1.3}$ & 0.876 & 0.000 & Valid \\
\hline $\mathrm{X}_{1.4}$ & 0.844 & 0.000 & Valid \\
\hline \multicolumn{4}{|c|}{ Subjective norm $\left(\mathbf{X}_{2}\right)$} \\
\hline $\mathrm{X}_{2.1}$ & 0.824 & 0.000 & Valid \\
\hline $\mathrm{X}_{2.2}$ & 0.882 & 0.000 & Valid \\
\hline $\mathbf{X}_{2.3}$ & 0.869 & 0.000 & Valid \\
\hline $\mathrm{X}_{2.4}$ & 0.855 & 0.000 & Valid \\
\hline \multicolumn{4}{|c|}{ Perceived behavioral control $\left(\mathrm{X}_{3}\right)$} \\
\hline $\mathrm{X}_{3.1}$ & 0.823 & 0.000 & Valid \\
\hline $\mathbf{X}_{3.2}$ & 0.858 & 0.000 & Valid \\
\hline $\mathbf{X}_{3.3}$ & 0.799 & 0.000 & Valid \\
\hline $\mathbf{X}_{3.4}$ & 0.816 & 0.000 & Valid \\
\hline $\mathrm{X}_{3.5}$ & 0.767 & 0.000 & Valid \\
\hline $\mathbf{X}_{3.6}$ & 0.782 & 0.000 & Valid \\
\hline \multicolumn{4}{|c|}{ Country of origin (M) } \\
\hline $\mathbf{M}_{1.1}$ & 0.757 & 0.000 & Valid \\
\hline $\mathbf{M}_{1.2}$ & 0.789 & 0.000 & Valid \\
\hline $\mathbf{M}_{1.3}$ & 0.829 & 0.000 & Valid \\
\hline$M_{1.4}$ & 0.780 & 0.000 & Valid \\
\hline $\mathbf{M}_{1.5}$ & 0.841 & 0.000 & Valid \\
\hline $\mathbf{M}_{1.6}$ & 0.800 & 0.000 & Valid \\
\hline M1.7 & 0.815 & 0.000 & Valid \\
\hline M1.8 & 0.815 & 0.000 & Valid \\
\hline \multicolumn{4}{|c|}{ Purchase intention (Y) } \\
\hline $\mathbf{Y}_{1}$ & 0.881 & 0.000 & Valid \\
\hline $\mathbf{Y}_{2}$ & 0.769 & 0.000 & Valid \\
\hline $\mathbf{Y}_{3}$ & 0.785 & 0.000 & Valid \\
\hline $\mathbf{Y}_{4}$ & 0.818 & 0.000 & Valid \\
\hline
\end{tabular}

\subsection{Average variance extracted (AVE)}

AVE illustrates the average variance on each variable so that the measurement of each the item to share the others measurements can be known.

Table 2. Average Variance Extracted (AVE)

\begin{tabular}{|l|c|}
\hline & Average Variance Extracted (AVE) \\
\hline Attitude $\left(\mathrm{X}_{1}\right)$ & 0.725 \\
\hline Subjective norm $\left(\mathrm{X}_{2}\right)$ & 0.736 \\
\hline Perceived behavioral control $\left(\mathrm{X}_{3}\right)$ & 0.653 \\
\hline Country of origin $(\mathrm{M})$ & 0.646 \\
\hline Purchase intention $(\mathrm{Y})$ & 0.663 \\
\hline
\end{tabular}

In Table 2, the AVE value for the attitude $\left(\mathrm{X}_{1}\right)$ variable is 0.725 ; subjective norm $\left(\mathrm{X}_{2}\right)$ variable of 0.736 ; perceived behavioral control $\left(\mathrm{X}_{3}\right)$ variable of 0.653 ; purchase intention (Y) variable of 0.663 ; and country of origin $(\mathrm{M}) 0.646$. At the minimum value must be of 0.5 , all indicators in each variable have converged with other items. 


\subsection{Discriminant validity}

The output of the value discriminant validity by processing data on PLS the results of data in the following Table 3.

Based on Table 3, overall constructs of the constructors are stated to have good discrimination, as the value of the correlation of indicators of the construct is greater than the values of the correlation between indicators with other constructs.

Table 3. Cross loading

\begin{tabular}{cccccc}
\hline & $\begin{array}{c}\text { Attitude Subjective norm } \\
\left(\mathbf{X}_{\mathbf{1}}\right)\end{array}$ & $\begin{array}{c}\text { Perceived behavioral } \\
\text { control }\left(\mathbf{X}_{\mathbf{3}}\right)\end{array}$ & $\begin{array}{c}\text { Purchase intention } \\
(\mathbf{Y})\end{array}$ & $\begin{array}{c}\text { Country of } \\
\text { origin }(\mathbf{M})\end{array}$ \\
\hline$X_{1.1}$ & $\mathbf{0 . 8 2 7}$ & 0.691 & 0.588 & 0.690 & 0.698 \\
$X_{1.2}$ & $\mathbf{0 . 8 5 8}$ & 0.736 & 0.663 & 0.674 & 0.719 \\
$X_{1.3}$ & $\mathbf{0 . 8 7 6}$ & 0.702 & 0.650 & 0.700 & 0.726 \\
$X_{1.4}$ & $\mathbf{0 . 8 4 4}$ & 0.656 & 0.623 & 0.670 & 0.693 \\
$X_{2.1}$ & 0.664 & $\mathbf{0 . 8 2 4}$ & 0.697 & 0.708 & 0.753 \\
$X_{2.2}$ & 0.774 & $\mathbf{0 . 8 8 2}$ & 0.708 & 0.712 & 0.775 \\
$X_{2.3}$ & 0.663 & $\mathbf{0 . 8 6 9}$ & 0.617 & 0.595 & 0.760 \\
$X_{2.4}$ & 0.701 & $\mathbf{0 . 8 5 5}$ & 0.614 & 0.655 & 0.738 \\
$X_{3.1}$ & 0.590 & 0.619 & $\mathbf{0 . 8 2 3}$ & 0.785 & 0.755 \\
$X_{3.2}$ & 0.658 & 0.642 & $\mathbf{0 . 8 5 8}$ & 0.765 & 0.758 \\
$X_{3.3}$ & 0.676 & 0.635 & $\mathbf{0 . 7 9 9}$ & 0.771 & 0.694 \\
$X_{3.4}$ & 0.572 & 0.619 & $\mathbf{0 . 8 1 6}$ & 0.679 & 0.661 \\
$X_{3.5}$ & 0.541 & 0.587 & $\mathbf{0 . 7 6 7}$ & 0.653 & 0.630 \\
$X_{3.6}$ & 0.545 & 0.634 & $\mathbf{0 . 7 8 2}$ & 0.663 & 0.667 \\
$Y_{.1}$ & 0.665 & 0.699 & 0.814 & $\mathbf{0 . 8 8 1}$ & 0.768 \\
$Y_{.2}$ & 0.615 & 0.577 & 0.632 & $\mathbf{0 . 7 6 9}$ & 0.645 \\
$Y_{.3}$ & 0.673 & 0.587 & 0.697 & $\mathbf{0 . 7 8 5}$ & 0.723 \\
$Y_{.4}$ & 0.663 & 0.671 & 0.757 & $\mathbf{0 . 8 1 8}$ & 0.696 \\
$M_{1.1}$ & 0.606 & 0.614 & 0.597 & 0.687 & $\mathbf{0 . 7 5 7}$ \\
$M_{1.2}$ & 0.663 & 0.711 & 0.705 & 0.703 & $\mathbf{0 . 7 8 9}$ \\
$M_{1.3}$ & 0.701 & 0.709 & 0.703 & 0.710 & $\mathbf{0 . 8 2 9}$ \\
$M_{1.4}$ & 0.645 & 0.689 & 0.726 & 0.720 & $\mathbf{0 . 7 8 0}$ \\
$M_{1.5}$ & 0.691 & 0.769 & 0.704 & 0.693 & $\mathbf{0 . 8 4 1}$ \\
$M_{1.6}$ & 0.677 & 0.726 & 0.696 & 0.708 & $\mathbf{0 . 8 0 0}$ \\
$M_{1.7}$ & 0.718 & 0.719 & 0.698 & 0.686 & $\mathbf{0 . 8 1 5}$ \\
$M_{1.8}$ & 0.649 & 0.730 & 0.707 & 0.692 & $\mathbf{0 . 8 1 5}$ \\
\hline & & & & &
\end{tabular}

\subsection{Composite reliability}

Another test is the composite reliability of the indicator block that measures the construct [14]. A construct is said to be reliable if the composite reliability value is above 0.70 .

Table 4. Composite reliability

\begin{tabular}{|l|c|}
\hline & Composite reliability \\
\hline Attitude $\left(\mathrm{X}_{1}\right)$ & 0.913 \\
\hline Subjective norm $\left(\mathrm{X}_{2}\right)$ & 0.918 \\
\hline Perceived behavioral control $\left(\mathrm{X}_{3}\right)$ & 0.919 \\
\hline Country of origin $(\mathrm{M})$ & 0.936 \\
\hline Purchase intention $(\mathrm{Y})$ & 0.887 \\
\hline
\end{tabular}

Table 4, give information for all constructs fulfill the value of composite reliability, then each variable in the study can be said to be reliable and further testing can be done. This 
value that in a composite manner, all variables in Tabel 4 the composite reliability have adequate internal consistency measuring that is measured.

\subsubsection{Cronbach alpha}

The reliability test is strengthened with Cronbach alpha.

Table 5. Cronbach alpha's

\begin{tabular}{|l|c|}
\hline & Cronbach Alpha \\
\hline Attitude $\left(\mathrm{X}_{1}\right)$ & 0.913 \\
\hline Subjective norm $\left(\mathrm{X}_{2}\right)$ & 0.918 \\
\hline Perceived behavioral control $\left(\mathrm{X}_{3}\right)$ & 0.919 \\
\hline Country of origin $(\mathrm{M})$ & 0.936 \\
\hline Purchase intention $(\mathrm{Y})$ & 0.887 \\
\hline
\end{tabular}

Based on Table 5, it can be seen that the value of Cronbach alpha for attitude, subjective form, perceived behavioral control, country of origin and purchase intention and all variable are $>0.70$. Thus, these results can indicate that each research variable has met the requirements of the Cronbach alpha value.

\subsubsection{Inner model}

Analysis using PLS then it is necessary to calculate the R-Square value for each dependent variable while for the independent variable value is absent because it is a predictive variable. R-square value will determine the model is feasible as a variable that has a substantive effect. For endogenous latent variables in the structural model that have an RSquare result of 0.67 is "good," R-Square of 0.33 indicates is "moderate," R-Square of 0.19 indicates that the model is "weak" [14]. PLS output as described below:

Tabel 6 R-Square value

\begin{tabular}{|l|c|}
\hline & R Square \\
\hline Attitude $\left(\mathrm{X}_{1}\right)$ & \\
\hline Subjective norm $\left(\mathrm{X}_{2}\right)$ & \\
\hline Perceived behavioral control $\left(\mathrm{X}_{3}\right)$ & \\
\hline Purchase Intention $(\mathrm{Y})$ & 0.855 \\
\hline
\end{tabular}

Based on Table 6, the attitude, subjective norm, and perceived behavioral control variables that influence the Purchase Intention variable in the structural model have the $\mathrm{R}$-Square value of 0.855 , which indicates that attitude, subjective norm, and perceived behavioral control in influencing purchase intention by $85.5 \%$ while the remaining $14.5 \%$.

\subsubsection{Hypothesis testing}

The results of the research hypothesis are summarized in Table 7. 
Tabel 7. Hypothesis test result

\begin{tabular}{|c|c|c|c|c|}
\hline & $\begin{array}{c}\text { Original } \\
\text { sample (O) }\end{array}$ & $\begin{array}{l}\text { Sample } \\
\text { mean } \\
(\mathbf{M})\end{array}$ & $\begin{array}{l}\text { Standard } \\
\text { deviation } \\
\text { (STDEV) }\end{array}$ & $\begin{array}{c}\text { T statistics } \\
(|\mathrm{O} / \mathrm{STDEV}|)\end{array}$ \\
\hline Attitude $\left(\mathrm{X}_{1}\right)$-> Purchase intention $(\mathrm{Y})$ & 0.218 & 0.215 & 0.060 & 3.614 \\
\hline Subjective norm $\left(\mathrm{X}_{2}\right)$-> Purchase intention $(\mathrm{Y})$ & -0.070 & -0.058 & 0.067 & 1.049 \\
\hline $\begin{array}{l}\text { Perceived behavioral control }\left(\mathrm{X}_{3}\right) \text {-> Purchase } \\
\text { intention }(\mathrm{Y})\end{array}$ & 0.557 & 0.541 & 0.117 & 4.773 \\
\hline $\begin{array}{l}\text { Attitude }\left(\mathrm{X}_{1}\right)->\text { Country of origin }(\mathrm{M})-> \\
\text { Purchase intention }(\mathrm{Y})\end{array}$ & -0.002 & -0.021 & 0.072 & 0.032 \\
\hline $\begin{array}{l}\text { Subjective norm }\left(\mathrm{X}_{2}\right)->\text { Country of origin }(\mathrm{M}) \text { - } \\
>\text { Purchase intention }(\mathrm{Y})\end{array}$ & -0.073 & -0.071 & 0.076 & 0.963 \\
\hline $\begin{array}{l}\text { Perceived behavioral control }\left(\mathrm{X}_{3}\right) \text {-> Country of } \\
\text { origin }(\mathrm{M}) \text {-> Purchase intention }(\mathrm{Y})\end{array}$ & 0.028 & 0.039 & 0.094 & 0.301 \\
\hline
\end{tabular}

\section{Discussion}

\subsection{The impact of attitude on purchase intention}

Based on the hypothesis testing for this study, it is found that attitude is influencing purchase intention on Korean brand products in Surabaya because of the statistic value of 3.614 , greater than 1.96 , which means that purchase intention can be formed with a good attitude. This means that the hypothesis that says "attitude has a positive influence on purchase intention," is acceptable. The influence that occurs between attitude with purchase intention is positive. This is obtained from the value of the original sample estimate of 0.218 , as the positive value indicates a direct effect that can be interpreted that the better the attitude of consumers in assessing a product, the more will drive themselves to make purchases on a product. Results of the analysis prove attitude has a significant impact on purchase intention can be interpreted if Korean brand products want to increase consumer buying interest, it is important which the consumer pay attention to evaluating and evaluating consumers towards Korean brand products as a form of attitude. This significant result is supported by the results of a study conducted by [2] wherein his research, it was found that attitude had a significant effect on purchase intention.

\subsection{The impact of subjective norms on purchase intention}

The results show that subjective norm does not affect purchase intention on Korean brand products in Surabaya because the T-statistic value is 1.049 , which means it is smaller than 1.96, which means that purchase intention may not be formed with a good subjective norm. This means that the hypothesis which says "subjective norm has a positive effect on purchase intention" is declared acceptable. The results of hypothesis testing obtained the value of the original sample estimate in the subjective norm relationship with the purchase intention is -0.070 . This value indicates the influence that is not unidirectional, so it can be interpreted that the higher the Subjective norm will further weaken the purchase intention. The results of the study prove that subjective norms do not have a significant effect on purchase intention; this research not supported the findings of research conducted by [2] which found subjective norms affect purchase intention. 


\subsection{The effect of perceived behavioral control on purchase intention}

Perceived behavioral control is influencing purchase intention on Korean brand products in Surabaya because the T-statistic value is 4.773 , greater than 1.96 , which means that purchase intention can be formed with good perceived behavioral control. This means that the hypothesis that says "Perceived behavioral control has a impact on purchase intention" is acceptable. The analysis proves that perceived behavioral control has a significant positive effect on purchase intention. This positive influence is proven by the value of the original sample estimate of 0.557 so that this positive effect can be interpreted that the better perceived behavioral control will increasingly have an impact on increased purchase intention. Vice versa, if the perceived behavioral control has decreased, it will further reduce consumer purchase intention. The results of the study prove that perceived behavioral control has a significant influence on purchase intention, which means that individual beliefs about certain factors will strengthen consumer interest in making purchases. This is supported by the results of research conducted by [2], which found a significant influence between perceived behavioral control and purchase intention.

\subsection{The effect of attitude on purchase intention moderated by country of origin}

The country of origin is not able to moderate or strengthen the influence of attitude on purchase intention. It is because the T-statistic value of 0.032 is less than 1.96. This means the hypothesis is not accepted. The results of the moderating test of the country of origin on the effect of attitude on purchase intention are obtained the original sample estimate value of -0.002 . This value indicates that the country of origin weakens the influence between attitude and purchase intention. The results in this study are in line with the findings of Chen in [15], who find country image having no direct impact on purchase decisions, and it has an indirect effect on purchase decisions through consumer brand attitude [15]. However, this is inversely proportional to the results of the analysis found by [2], which proves that attitude has a significant effect on purchase intention by being moderated by the country of origin. Because the influence of attitude on purchase intention will be stronger when the country of origin is also stronger. This influence shows the effect of positive interactions between attitude and country of origin.

\subsection{The impact of Subjective norm on purchase intention moderated by country of origin}

Based on the hypothesis testing for this study, it is proven that subjective norm had no significant effect on purchase intention moderated by country of origin on Korean brand products in Surabaya. The T-statistic value was 0.963 , smaller than 1.96, which is meant the country of origin is unable to moderate or strengthen the influence between subjective norms on Purchase Intention. This means the hypothesis is not accepted. The results of testing the country of origin moderation hypothesis on the influence of subjective norm on purchase intention obtained the value of the original sample estimate of -0.073 . This value indicates that the country of origin is not able to strengthen the relationship between Subjective norm and purchase intention. 


\subsection{The effect of perceived behavioral control on purchase intention moderated by country of origin}

Perceived behavioral control does not significantly influence purchase intention by being moderated by the country of origin on Korean brand products in Surabaya. The T-statistic value of 0.301 is less than 1.96 , which means that country of origin is unable to moderate the effect between perceived behavioral control on purchase intention. Based on the results of hypothesis testing conducted on the relationship of perceived behavioral control to purchase intentions moderated by the country of origin, the original sample estimate is 0.028. This value indicates that the direction of positive influence so that it can be interpreted that the country of origin can strengthen the relationship between perceived behavioral control on purchase intention, but the effect is small. The results in this study are in line with the theory proposed by Ajzen [3], which states that intentions and perceived behavioral control are influential on a behavior carried out by individuals.

\section{Conclusion}

The rising in attitude will make someone intend to buy Korean brand products. Similarly, perceived behavioral control would do. Individual beliefs about certain factors will strengthen consumer interest in making purchases. On the other hand, the subjective norm does not affect the purchase intention of Korean brand products in Surabaya. This is indicated by the higher Subjective norm that does not affect the rise or fall of prospective consumers' buying intentions. Furthermore, the country of origin cannot also be moderating on the effect of attitude and perceived behavioral control on the ups and downs of buying intentions of Korean brand products.

In this case, promotions through advertisements, product packaging, detailed product information that can be accessed by consumers, and the distribution of official stands will be able to attract consumers to intend to buy Korean brand products. Meanwhile, for future research, it is necessary to add more samples to produce better research because this research sample is only limited to one Korean skincare product.

\section{References}

1. E. Pramita, Industri Kecantikan di Indonesia Alami Pertumbuhan Pesat [Beauty Industry in Indonesia Experience Rapid Growth]. [Onine] from http://majalahkartini.co.id/mode-kecantikan/kecantikan/industri-kecantikan-diindonesia-alami-pertumbuhan-pesat/ (2017). [in Bahasa Indonesia].

2. H. Chia-Lin, C. Chi-Ya, Y. Chutinart, Journal of Retailing and Consumer Services, 3(C):145-152(2017). https://ideas.repec.org/a/eee/joreco/v34y2017icp145-152.html

3. I. Ajzen, Constructing a TPB questionnaire: Conceptual and methodological considerations, [Occasional paper], (2006). p. 1-14. https://pdfs.semanticscholar.org/0574/b20bd58130dd5a961f1a2db10fd1fcbae95d.pdf

4. I. Ajzen, Attitudes, Personality, and Behavior, UK: Open University Press-McGraw Hill Education (2005). https://books.google.co.id/books?id=dmJ9EGEy0ZYC\&dq=

5. N.J. Setiadi, Perilaku konsumen. [Consumer behavior], Jakarta: Prenadademia Group (2008). [in Bahasa Indonesia]. http://prenadamedia.com/shop/perilaku-konsumen/

6. R. Veithzal, Manajemen sumber daya manusia untuk perusahaan. [Human resource management for companies], PT. Raja Grafindo Persada: Jakarta (2008). [in Bahasa Indonesia]. http://www.rajagrafindo.co.id/produk/manajemen-sumber-daya-manusia/

7. E. Listiana, S.E. Elida, Media Ekonomi dan Manajemen 29,1:1-14(2014). [in Bahasa Indonesia].http://repository.polnep.ac.id/xmlui/handle/123456789/1748 
8. P. Kotler, K.K., Keller, Manajemen Pemasaran. [Marketing Management]. Jakarta: Erlangga (2009). [in Bahasa Indonesia]. https://onesearch.id/Author/Home?author=Kotler\%2C+Philip+\%7C+Keller\%2C+Kevi $\underline{n+L a n e}$

9. L.G. Schiffman, L.L. Kanuk, H. Hansen, Consumer Behaviour. USA: Prentice Hall, (2012). https://books.google.co.id/books?id=kf9TuQAACAAJ

10. N.S.N.M. Yunus, Procedia Economics and Finance, 37,2016:343-349(2016). https://www.sciencedirect.com/science/article/pii/S2212567116301356

11. Marhaini, Jurnal Manajemen Bisnis, 1,3:89-96(2008). [in Bahasa Indonesia]. https://www.academia.edu/4915064/JURNAL_MANAJEMEN_BISNIS

12. M. Tan, S.H.T. Thompson. Journal of the Association for Information Systems, 1,5:142(2000). https://aisel.aisnet.org/cgi/viewcontent.cgi?article $=1188 \&$ context=jais

13. F. Hair, Joseph, C. Ringle, M. Sarstedt. Long Range Planning, 46,15:1-12(2002). https://www.researchgate.net/publication/319669432_Partial_Least_Squares_Structura 1_Equation_Modeling

14. I. Ghozali. Structural Equation Modeling Metode Alternatif dengan Partial Least Square (PLS). [Structural Equation Modeling Alternative Methods with Partial Least Square (PLS)], Semarang: Badan Penerbit Universitas Diponegoro, (2011). [in Bahasa Indonesia]. https://digilib.undip.ac.id/v2/2012/10/04/structural-equation-modelingmetode-alternatif-dengan-partial-least-square/

15. L.I. Dongjin, A. Jong-Seok, Z. Ronghai, W. Bo. Front. Bus. Res. China, 3,4:621646(2009). https://link.springer.com/content/pdf/10.1007\%2Fs11782-009-0030-2.pdf 